\title{
Performance Analysis of a Hybrid District Heating System: A Case Study of a Small Town in Croatia
}

\author{
Robert Mikulandric ${ }^{* 1,2}$, Goran Krajačić ${ }^{3}$, Neven Duićt, Gennadii Khavin ${ }^{5}$, \\ Henrik Lund $^{6}$, Brian Vad Mathiesen ${ }^{7}$, Poul Ostergaard ${ }^{8}$
}

${ }^{1}$ Department of Biosystems, Faculty of Bioscience Engineering, KU Leuven, Kasteelpark Arenberg 20, 3000 Leuven, Belgium

e-mail: robert.mikulandric@ biw.kuleuven.be

${ }^{2}$ Department of Energy, Power Engineering and Ecology, Faculty of Mechanical Engineering and Naval Architecture, University of Zagreb, Ivana Lučića 5, 10002 Zagreb, Croatia

${ }^{3}$ Department of Energy, Power Engineering and Ecology, Faculty of Mechanical Engineering and Naval Architecture, University of Zagreb, Ivana Lučića 5, 10002 Zagreb, Croatia e-mail: goran.krajacic@fsb.hr

${ }^{4}$ Department of Energy, Power Engineering and Ecology, Faculty of Mechanical Engineering and Naval Architecture, University of Zagreb, Ivana Lučića 5, 10002 Zagreb, Croatia e-mail: neven.duic@fsb.hr

${ }^{5}$ The National Technical University "Kharkiv Polytechnic Institute", Frunze Street 21, Kharkiv, Ukraine e-mail: gennadiy.khavin@mail.ru

${ }^{6}$ Department of Development and Planning, Aalborg University, Fibigerstraede 13, 9220 Aalborg, Denmark e-mail: lund@plan.aau.dk

${ }^{7}$ Department of Development and Planning, Aalborg University, A.C. Meyers Vænge 15, Room A2, 2450 Copenhagen SV, Denmark e-mail: bvm@plan.aau.dk

${ }^{8}$ Department of Development and Planning, Aalborg University, Fibigerstraede 13, 9220 Aalborg, Denmark

e-mail: poul@plan.aau.dk environ. syst., 3(3), pp 282-302, 2015, DOI: http://dx.doi.org/10.13044/j.sdewes.2015.03.0022

\begin{abstract}
Hybridisation of district heating systems can contribute to more efficient heat generation through cogeneration power plants or through an increase in the share of renewable energy sources in total energy consumption while reducing negative aspects of particular energy source utilisation. In this work, the performance of a hybrid district energy system for a small town in Croatia has been analysed. A mathematical model for process analysis and optimisation algorithm for optimal system configuration have been developed and described. The main goal of the system optimisation is to reduce heat production costs. Several energy sources for heat production have been considered in 8 different simulation cases. Simulation results show that the heat production costs could be reduced with introduction of different energy systems into an existing district heating system. Renewable energy based district heating systems could contribute to heat production costs decrease in district heating systems up to $30 \%$ in comparison with highly efficient heat production technologies based on conventional fuels.
\end{abstract}

\section{KEYWORDS}

District heating system hybridisation, Renewable energy systems, District heating system analysis, System optimisation.

\footnotetext{
* Corresponding author
} 


\section{INTRODUCTION}

\section{Potential of district heating systems}

A District Heating System (DHS) should be a reliable, efficient and safe system that supplies energy for space and water heating to residential homes and commercial buildings. DHS can provide highly efficient heat generation and environmental and economic benefits to communities and energy consumers [1]. DHS significantly contributes to achieve national energy policy objectives, especially those concerning increasing share of renewable sources of energy in total energy consumption [2-4]. In addition, they provide higher overall efficiencies [5] and higher customer satisfaction [6]. The research conducted by Connolly et al. [7] has showed that the expansion of district heating systems could decrease the European primary energy consumption by $7 \%$, fossil fuels by $9 \%$, and the carbon dioxide emissions by $13 \%$ while still supplying exactly the same energy services. The future potential of DHS depends on its possibility to meet heat demands through highly efficient and flexible heat production with a high share of renewable energy sources. DHS flexibility can be improved by introducing heat storage systems [8], improvement of system control technology [9] or system hybridisation [10]. The economics of DHS depends on the production cost of the thermal energy, the cost of the thermal energy distribution network (which depends on network size), DHS thermal loads and customer connection costs. DH systems are generally more feasible in densely populated urban areas with high-density building clusters and industrial complexes rather than low-density residential areas where heat demand density is low [11].

\section{Overview of the status of DHS in Eastern European countries}

In the Eastern European countries, heating systems are a legacy of the centralized economic planning and have been traditionally the most important source of heat for space heating in highly populated urban areas. However, one of the most important problems related to DHS in these countries is the high thermal plant and combined power plant operating and maintenance costs which exceeded revenue from produced heat and power. Hence district heating companies do not have economic interest to invest in system modernisation or expansion. These problems, together with the social problems and "energy poverty" (difficulty in paying the bills), are important issues that still need to be resolved. National energy plans, strategies and recommendations $[12,13]$ generally support development of DHS in terms of market liberalisation, reliability and efficiency improvement of the DHS, better DH regulation (heat metering, energy plans, demand forecasts) and reduction of operation and production costs. In Croatia, DHS cover around $10 \%$ of household heating requirements and it is reasonable to say that this share will increase within this decade [13]. The rest of the heating requirements is covered by small, on-site fossil fuelled, biomass or electrical boilers. Further development of DHS (especially those based on combined heat and power technology) is limited by relatively high fossil fuel prices and transportation problems, low DHS efficiency, seasonal heating character and lack of large heat consumers (industry).

\section{Energy sources of district heating systems}

It is widely accepted that the Combined Heat and Power (CHP) or trigeneration [14, 15] plants are an energy-efficient technology due to simultaneous production of heat and electricity. CHP generation may result in consistent energy conservation up to 30\% [16] and could contribute to grid energy balancing processes with a large number of renewable energy systems $[17,18]$. The economic viability of CHP-DH networks depends on the optimisation and engineering of the DHS, national regulatory framework [14] and financial and economic factors [20]. 
Renewable energy sources, especially biomass or those that are under government subsidy are slowly increasing their share. They are increasingly applied in district heating systems either stand-alone or as a supplement to traditional fossil fuels. Solar and geothermal energy are becoming also very popular in countries where their use is under subsidy. A lot of new biomass based DHS installations have been realised during the last decade, mostly in Scandinavian countries, Germany and Eastern Europe [21]. Biomass district heating systems in Eastern European countries that are EU members have been more extensively used in the last decade and there are currently more than 20 biomass DH systems in operation [22]. The share of these systems in fulfilling overall heating demand is still relatively small. Biomass based district heating systems are generally an effective way to increase the use of renewable energy sources in highly populated urban areas.

The use of the high temperature geothermal energy for heat production conserves non-renewable fossil fuels and thereby decreases emissions. The utilization modes of geothermal energy for heating in buildings can be divided into three categories: direct, step utilization and geothermal heat pumps [23]. Low and moderate temperature geothermal energy could also be used as a Geothermal Heat Pump (GHP) to increase efficiency and to reduce the operational costs of existing heating and/or cooling systems. Heat pumps use less energy than traditional heating systems because they use the earth as a heat source whose temperature is more constant than the outside air. Geothermal pump systems can reach a Coefficient Of Performance (COP) up to 6 and can reduce building's energy consumption by $30-50 \%$, compared to the conventional electric heating [24]. Even if their temperature level is too low for direct heating purposes, they could be suitable as a heat source for heat pumps in combination with a high-temperature heat source. Geothermal energy may also be utilised in combination with heat exchangers and air heat pumps [25]. In combination with gas boilers, this technology reduces the system's total fuel demand as the efficiency of the system is higher [26].

An Air-source Heat Pump (AHP) extracts heat from the air, concentrates it and transfers it to indoors or outdoors, depending on the season. These units generally are more suited to mild climates for heating because their capacity is limited by size [27, 28]. Air temperatures fluctuate considerably, so coefficient of performance of these kinds of heat pumps varies considerably during the day. Heat pumps and, in particular systems that integrate heat pumps and cogeneration units, could offer a significant potential for greenhouse gas reduction [29, 30].

Thermal Storage Systems (TSS) comprise technologies that store thermal energy in energy storage reservoirs for later use. In district heating systems, thermal energy storage systems are mostly used for short-term thermal storages. Short term water storage in steel tanks is a traditional feature of CHP systems. The main reason for short-term storage is to balance the heat production in general, and particularly during peak load periods. Advantages of short-term thermal storage are: reduction of partial load operation and increase in power generation [3].

\section{Hybridisation of district heating systems}

The hybridisation of a DHS combines two or more renewable or non-renewable energy sources for heat production. Particular energy sources could complement each other on daily and yearly basis and therefore reduce negative aspects of a particular energy source utilisation [31]. In district heating systems, hybridisation could be performed through utilisation of renewable and non-renewable energy sources. In order to research possibilities to reduce heat production costs and to improve efficiency of a particular heating system with DHS hybridisation, several studies have been performed. Li et al. [32] coupled absorption heat pumps with municipal DH network and concluded 
that both heating capacity and the energy efficiency of the DH system could be improved. Blake et al. [33] showed that a hybrid DHS that consists of a heat pump and a CHP unit offers significant reductions in fuel consumption and operational costs. Scarpa et al. [34] analysed the performance of a hybrid DHS composed of a heat pump and a gas boiler. A hybrid DHS composed of heat pumps and a thermal storage was analysed in research done by Pardo et al. [35]. Hackel et al. [36] studied the performance of a hybrid DHS where a ground source heat pump was combined with a gas boiler. Coskun et al. [9] proposed a hybrid system that is consisted of a biogas based electricity production and a water-to-water geothermal heat pump unit for improving the efficiency of geothermal district heating systems. These studies have been focused mostly on the efficiency and system design improvement.

Li et al. [37] analysed influence of different operation strategies of a hybrid system that consists of a centrifugal heat pump and a gas boiler on energy production costs. Pirouti et al. [38] showed that a DHS operating strategy has a great influence on annual DHS performance. Optimisation of district heating network configuration has been done by Li et al. [39]. Operation strategy of different renewable energy sources for zero $\mathrm{CO}_{2}$ emission region has been presented by Morel et al. [40].

However, a comprehensive matching analysis for the hybrid energy systems that involve various energy forms on a DHS performance is still lacking [41]. In the research performed by Sundberg et al. [42, 43] a comprehensive analysis of a municipal hybrid energy system configuration has been conducted. However, heat demands are considered only on yearly and seasonal level and facility efficiency changes due to partial loads have been neglected.

In this work, the economic performance and the operation strategy analysis that incorporates several district heating technologies (a CHP system, a biomass based boiler, heat pumps and a thermal storage system) has been done for Pokupsko district (Croatia). Optimal operation of DHS facilities has been defined on an hourly basis. Several cases have been simulated in order to analyse economical potential of different hybrid district heating systems and optimal system configuration has been defined.

\section{MATHEMATICAL MODEL}

The scope of this work is the performance analysis of a hybrid district heating system (that will be described in the next section) in terms of distributed heat and heat production costs. A mathematical model that finds the optimal hourly heat production load of particular heat production facility in the hybrid district heating system is developed. Calculation has been performed in MATLAB ${ }^{\circledR}$ software package. The objective of the optimisation is to find the optimal set of heat production operation loads for particular system to meet DHS heat demand (set by goal function - eq. (1) in order to minimise costs of heat production for DHS (set by optimisation function - eq. (2). Optimisation has been conducted for several cases of hybrid district heating system types.

The goal function is set to meet hourly $(h)$ heat demand $\left(P_{t h D H S}\right)$ in the hybrid DHS $(i)$ in one average day for a particular month $(m)$. The goal function can be described:

$$
P_{t h D H S, h m}=\sum_{i=1}^{6} P_{t h, i h m} \quad \text { for } \quad i=1-6, h=1-24, m=1-12
$$

The first optimisation goal is to find an optimal set of heat production operation loads in order to minimise hourly heat production cost $\left(C_{t h D H S}\right)$. Eq. (2) describes hourly expenditure for the heat production $\left(C_{t h D H S}\right)$ where investment and operation and maintenance costs are not included: 


$$
C_{t h D H S, h m}=\sum_{i=1}^{6} C_{t h, i h m} \quad \text { for } \quad i=1-6, h=1-24, m=1-12
$$

The optimisation function can be described:

$$
\min C_{t h D H S, h m}\left\{\begin{array}{c}
\sum_{i=1}^{6} P_{t h, i h m}=P_{t h D H S, h m} \quad \text { for } i=1-6, h=1-24, m=1-12 \\
P_{t h \min , i h m} \leq P_{t h, i h m} \leq P_{t h \max , i h m}
\end{array}\right. \text {. }
$$

Equations that describe a particular heat production facility performance are shown in Table 1 (eq. 4 - eq. 15). The efficiency of CHP production plant is given as a function of the ratio between delivered heat and power (eq. 4), followed by efficiency of an air heat pump as a function of ambient temperature and delivered temperature (eq. 6), efficiency of a ground heat pump where temperature of ground has been taken as constant (eq. 8), efficiency of biomass boiler as a function of thermal load (eq. 10) and efficiency of thermal heat storage as a function of heat losses (eq. 14). Eqs 5, 7, 9, 11, 13 and 15 describe heat production costs for particular DHS technology. Convection coefficient for heat losses calculation in a TSS has been calculated for slowly moving air. The average TSS area $\left(A_{6}\right)$ has been determined to be $52 \mathrm{~m}^{2} / \mathrm{MWh}$ of storage capability.

Table 1. District heating facility performance

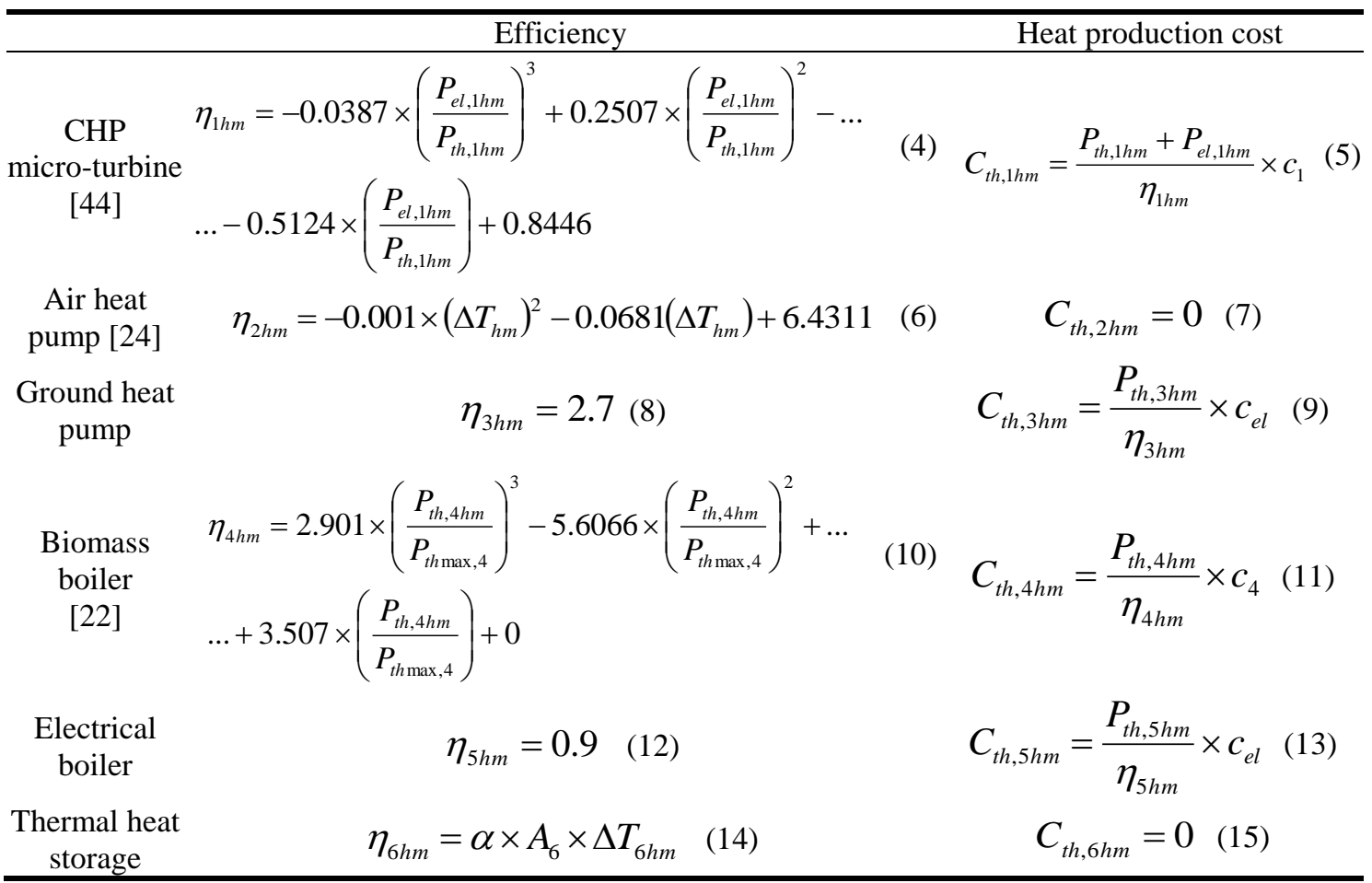

In order to calculate total hourly heat production costs ( $C_{\text {totDHS }}$ - described in eq. 13) investment, and Operation and Maintenance (O\&M) costs are added. Investment, and operation and maintenance costs are averaged on hourly basis as function of total investment costs $\left(c_{i n}\right)$, yearly O\&M costs $\left(c_{O \& M}\right)$, economic lifetime $(y)$ and discount rate $(r)$. These costs are evenly distributed (and constant) through the whole year for 
every hour in the year (eq. 14). Average yearly heat production costs (per MWh of produced heat) are then calculated (eq. 15).

$$
\begin{aligned}
C_{\text {totDHS,hm }}= & \sum_{i=1}^{6} C_{t h, i h m}+\sum_{i=1}^{6} C_{i n, i h m} \quad \text { for } \quad i=1-6, h=1-24, m=1-12 \\
C_{i n, i h m} & =\frac{\frac{c_{i n, i h m} \times(1+r)^{y}}{8}+c_{O \& M, i h m}}{8760} \quad \text { for } \quad i=1-6, h=1-24, m=1-12 \\
C_{a v D H S} & =\frac{\sum_{h=1}^{24} \sum_{m=1}^{12} C_{t o t D H S, h m}}{24 \times 12 \times \sum_{h=1}^{24} \sum_{m=1}^{12} P_{t h D H S, h m}} \quad \text { for } \quad h=1-24, m=1-12
\end{aligned}
$$

To solve the nonlinear constrained optimisation function with the described equations and constraints, MATLAB ${ }^{\circledR}$ nonlinear optimisation software has been used (FMINCON function). The detailed description of how the software works can be found in [45].

The goal of the second optimisation method is to find minimum average yearly heat production costs $\left(C_{a v D H S}\right)$ as function of DHS configuration (maximum thermal load of individual facilities). The scheme of this optimisation methodology for one considered facility is given in Figure 1. Second optimisation methodology uses investment costs, fuel costs and efficiency dependence of considered facilities as input variables. In the first iteration, maximum thermal outputs of considered facilities are assumed. Based on this information and predicted hourly heat demand for particular day in the month, the prediction of thermal storage charge or discharge is predicted. Afterwards, with use of nonlinear optimisation software for Nonlinear Constrained Optimisation (NCO) of the first optimisation function, the optimal facility operation during the year and average heat production costs are calculated. If the calculated average heat production cost is smaller than the average heat production cost that are calculated before, then current DHS configuration settings become optimal. At the end of the iteration process, the maximum capacity of the facility/facilities is increased by a certain number (defined by user) and the process is repeated. Table 2 presents input parameters related to particular investment costs, particular operation and maintenance costs, fuel costs, predicted economical lifetime and discount rate for considered DHT technologies.

Mathematical model consists of several constraints. A short description of each constraint follows:

- Power output of the CHP micro-turbine is set to be at its maximum. The goal is to maximise electricity production for high efficiency air heat pump:

$$
P_{e l, 1 \mathrm{hm}}=P_{e l \max , 1 \mathrm{hm}}
$$

- The heat production from the turbine in CHP facility is defined with the power output and thermal output ratio together with related efficiency and it is limited by the system operating characteristics. When the thermal output tends to be lower than designed minimum value, the facility is shut down: 


$$
P_{t h \min , 1 h m} \leq P_{t h, 1 h m} \leq P_{t h \max , 1 h m}
$$

- In cases where the air heat pump is not attached to the CHP facility, the electricity produced from the facility is sold to the utility based on current electricity prices (no subsidies) and the heat production costs are reduced by this number:

$$
C_{t h, 1 h m}=\frac{P_{t h, 1 h m}+P_{e l, 1 h m}}{\eta_{1 h m}} \times c_{1}-P_{e l, 1 h m} \times c_{e l}
$$

- The thermal storage system is charged with heat when the heat demand is lower than the maximum capacity of a DHS. When the heat demand is higher than the DHS heat production capacity, heat from the thermal storage system is discharged. When the thermal storage system is full (over $95 \%$ of its capacity $\left.Q_{6 \max }\right)$, the heat from the system is sequentially discharged in order to become empty at the end of a day. The thermal storage system cannot be charged and discharged at the same time (see Figure 1);

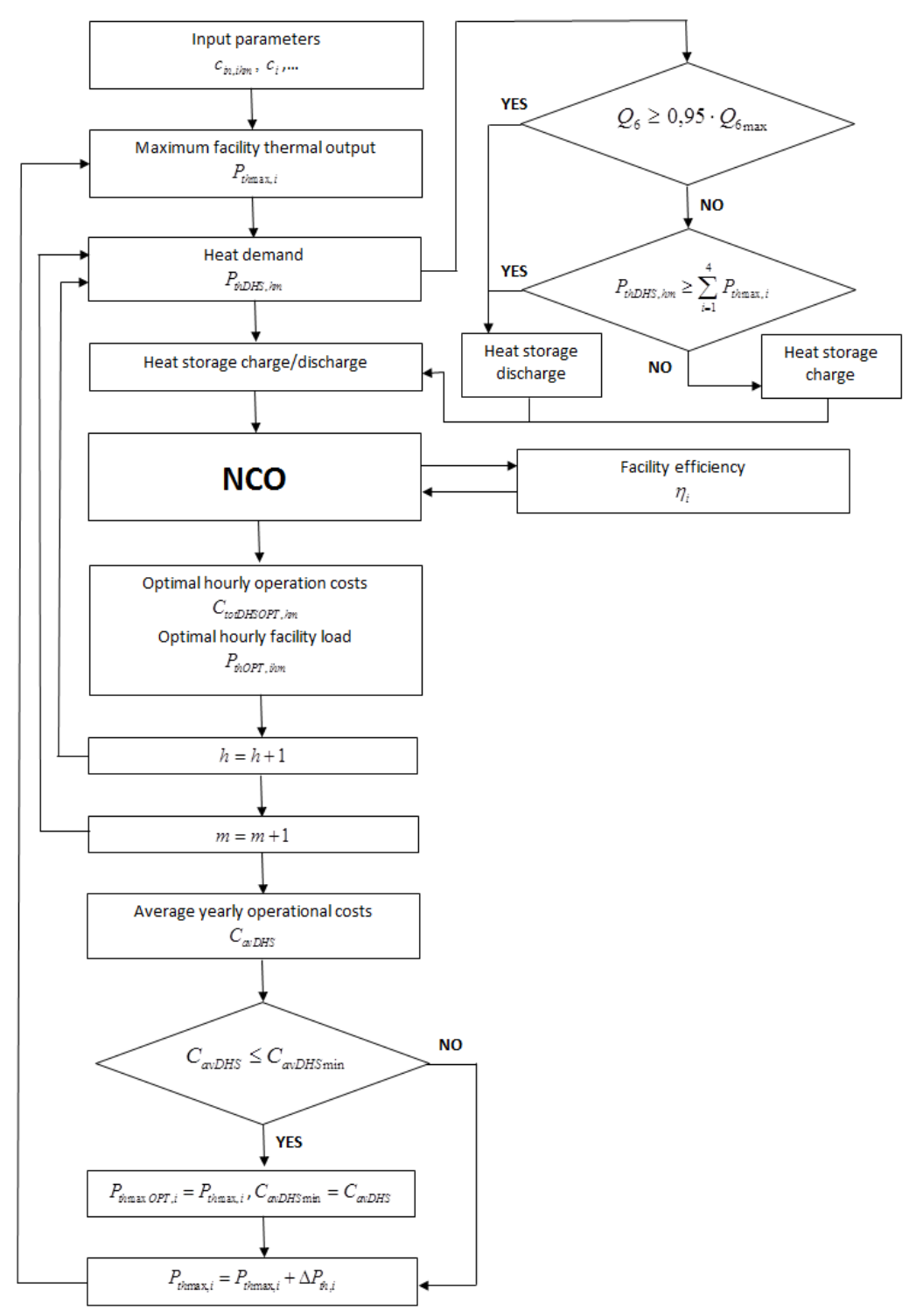

Figure 1. System optimisation scheme 
- Particular facility maximum thermal output is set to be lower or equal to the maximum thermal load of the DHS:

$$
P_{t h \max , i} \leq P_{t h D H S \max }
$$

Table 2. Model input parameters

\begin{tabular}{|c|c|c|c|c|c|c|}
\hline & $\begin{array}{c}\text { CHP } \\
\text { micro-turbine }\end{array}$ & $\begin{array}{l}\text { Air heat } \\
\text { pump }\end{array}$ & $\begin{array}{l}\text { Ground heat } \\
\text { pump }\end{array}$ & $\begin{array}{c}\text { Biomass } \\
\text { boiler }\end{array}$ & $\begin{array}{l}\text { Electrical } \\
\text { boiler }\end{array}$ & $\begin{array}{c}\text { Thermal heat } \\
\text { storage }\end{array}$ \\
\hline $\begin{array}{l}\text { Investment } \\
\text { cost }\end{array}$ & $\begin{array}{c}890 \\
\text { EUR/kW } \mathrm{el} \\
{[44]}\end{array}$ & $\begin{array}{c}590 \\
\text { EUR/kW } \\
{[46]}\end{array}$ & $\begin{array}{c}500 \\
\text { EUR/kW } \\
{[46]}\end{array}$ & $\begin{array}{c}520 \\
\text { EUR/kW } \\
{[47]}\end{array}$ & $\begin{array}{c}0 \mathrm{EUR}^{\mathrm{k} / \mathrm{kW}_{\text {th }}} \\
{[47]}\end{array}$ & $\begin{array}{c}3 \mathrm{EUR} / \mathrm{kWh} \\
{[48]}\end{array}$ \\
\hline O\&M costs & $\begin{array}{c}50 \\
\text { EUR/kW } / \mathrm{kW}_{\mathrm{e}} / \mathrm{a} \\
{[44]}\end{array}$ & $\begin{array}{c}50 \\
\text { EUR/kW } \\
{[49]}\end{array}$ & $\begin{array}{c}39 \\
\text { EUR/kW } / \mathrm{kh} / \mathrm{a} \\
{[49]}\end{array}$ & $\begin{array}{c}52 \\
\text { EUR/kW } / \mathrm{th} / \mathrm{a} \\
{[49]}\end{array}$ & $\begin{array}{c}8 \\
\text { EUR/kW } / \mathrm{el} / \mathrm{a} \\
{[47]}\end{array}$ & $\begin{array}{c}40 \\
\text { EUR/MWh/a } \\
{[48]}\end{array}$ \\
\hline Fuel cost & $\begin{array}{c}53 \\
\text { EUR/MWh } \\
{[50]}\end{array}$ & $\begin{array}{c}0 \\
\text { EUR/MWh }\end{array}$ & $\begin{array}{c}100 \\
\text { EUR/MWh } \\
{[51]}\end{array}$ & $\begin{array}{c}13 \\
\text { EUR/MWh } \\
{[52]}\end{array}$ & $\begin{array}{c}100 \\
\text { EUR/MWh } \\
{[51]}\end{array}$ & 0 EUR/MWh \\
\hline $\begin{array}{l}\text { Economical } \\
\text { lifetime }\end{array}$ & \multicolumn{6}{|c|}{15 years } \\
\hline $\begin{array}{l}\text { Discount } \\
\text { rate }\end{array}$ & \multicolumn{6}{|c|}{$10 \%$} \\
\hline
\end{tabular}

\section{POKUPSKO DISTRICT HEATING SYSTEM}

Pokupsko district is located in the central part of Croatia, $30 \mathrm{~km}$ south of Zagreb (Figure 2). This region generally offers a high potential in terms of biomass and biomass residues production. The population of Pokupsko is around 2,500. Pokupsko district plans to install biomass based DH system in the near future. DHS will be used for heating and hot water purposes. There are no large industrial facilities in that region that require large amount of high temperature water or steam.
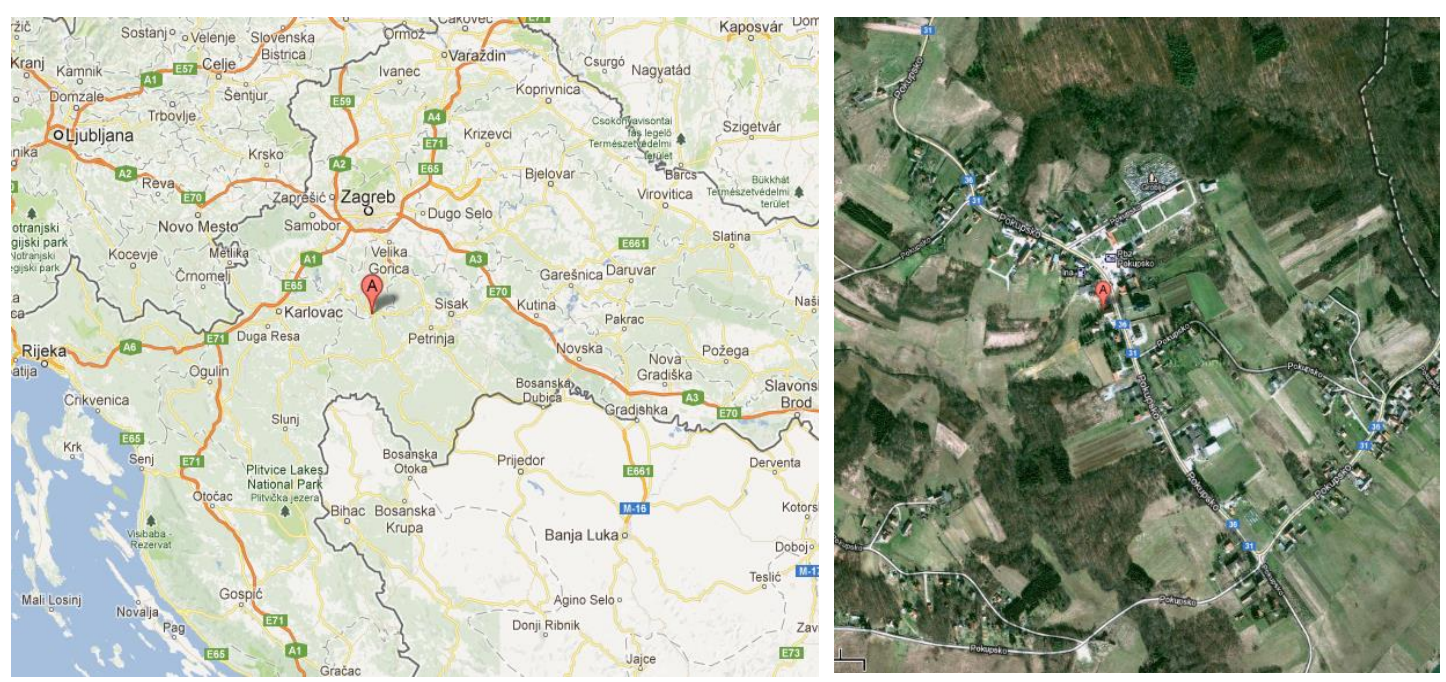

Figure 2. Location of Pokupsko district [53]

Heat produced from DHS will be used for residential household heating and hot water purposes. There are several individual heat consumers that require higher heat demand such as municipal building, elementary school and a market. A list of all heat consumers 
in Pokupsko district is shown in Table 3. The daily maximum heat load has been measured for an average day in December (presented data has been collected on 16.12.2010, 4:30 AM). The maximum heat load is $1,850 \mathrm{~kW}$.

Table 3. Heat consumers during the peak load in Pokupsko DHS

\begin{tabular}{cc}
\hline Consumers & Heat demand $[\mathrm{kW}]$ \\
\hline Households (60) & 470 \\
Residential building & 80 \\
Office buildings & 610 \\
Municipal building & 160 \\
Nursery school & 50 \\
Culture municipal building & 60 \\
Elementary school & 250 \\
Church & 25 \\
Market & 120 \\
Veterinary building & 25 \\
\hline Total & 1,850 \\
\hline
\end{tabular}

Due to absence of an industry (chemical or food industry) and requirements for high temperature water (hospitals, hotels) in Pokupsko district, lower outgoing temperature from heat production facilities could be obtained. That will also lead to lower heat losses in a district heating network. Therefore, designed outgoing temperature in Pokupsko DHS is $60{ }^{\circ} \mathrm{C}$ while returning temperature is $40{ }^{\circ} \mathrm{C}$. Other characteristics of Pokupsko DHS can be found in Table 4.

Table 4. Pokupsko DHS characteristics

\begin{tabular}{ccc}
\hline \multicolumn{3}{c}{ Pokupsko district heating system characteristics } \\
\hline Maximum heat load & {$[\mathrm{kW}]$} & 1,850 \\
Length of DHS network & {$[\mathrm{m}]$} & 2,940 \\
Outgoing temperature & {$\left[{ }^{\circ} \mathrm{C}\right]$} & 60 \\
Returning temperature & {$\left[{ }^{\circ} \mathrm{C}\right]$} & 40 \\
Number of heat consumers & - & 71 \\
\hline
\end{tabular}

The daily heat load trajectory in January was assumed to be similar as in Zagreb district heating system [54] due to similar climatic characteristics but the actual values have been fitted to match peak heat consumption for Pokupsko district. The daily heat load has 2 peaks. One heat load peak is around $5 \mathrm{AM}$ when the house heating systems are turning on and when there is higher demand for hot water. The second heat load peak is around 4 PM when people are coming home from their work (Figure 3). Heating degree days are one of the most important factors in defining heat demands for specific area. Therefore, the monthly heat load has been correlated with respect to the number of heating degree days in each month. Value of heating degree days has been gathered from [55] for Pokupsko district area. The highest peak load is in December (1.82 $\left.\mathrm{MW}_{\text {th }}\right)$ and in January (1.7 $\left.\mathrm{MW}_{\text {th }}\right)$ around 4 AM. During May, June, July and August heat load do not exceed $0.5 \mathrm{MW}_{\text {th }}$ (Figure 3 ).

The analysed hybrid district heating system will consist of an electrical heating boiler (connected to the electrical grid), a biomass fired boiler, a CHP micro-turbine, a ground heat pump that will be connected to an electrical grid, air heat pumps that will be connected to an electrical generator of the gas CHP micro-turbine and a thermal storage system (hot water tanks). The heat pumps are used as separate heat sources (if they meet 
the required temperature in DHS) or as water preheaters in CHP production process. Heat pumps raise the water temperature from the inlet temperature (assumed to be ambient air temperature or ground temperature) to the level that is required by DHS (in this case 60 ${ }^{\circ} \mathrm{C}$ ). If due to technical reasons the pumps are unable to reach this temperature, then the water is sent to CHP system to raise the temperature to the required level. The hybrid DHS scheme is presented in Figure 4. The outgoing and returning water temperatures inside of the DHS network have been assumed as constant. The capacity of hybrid DHS components will be varied in order to analyse their effect on system performance.

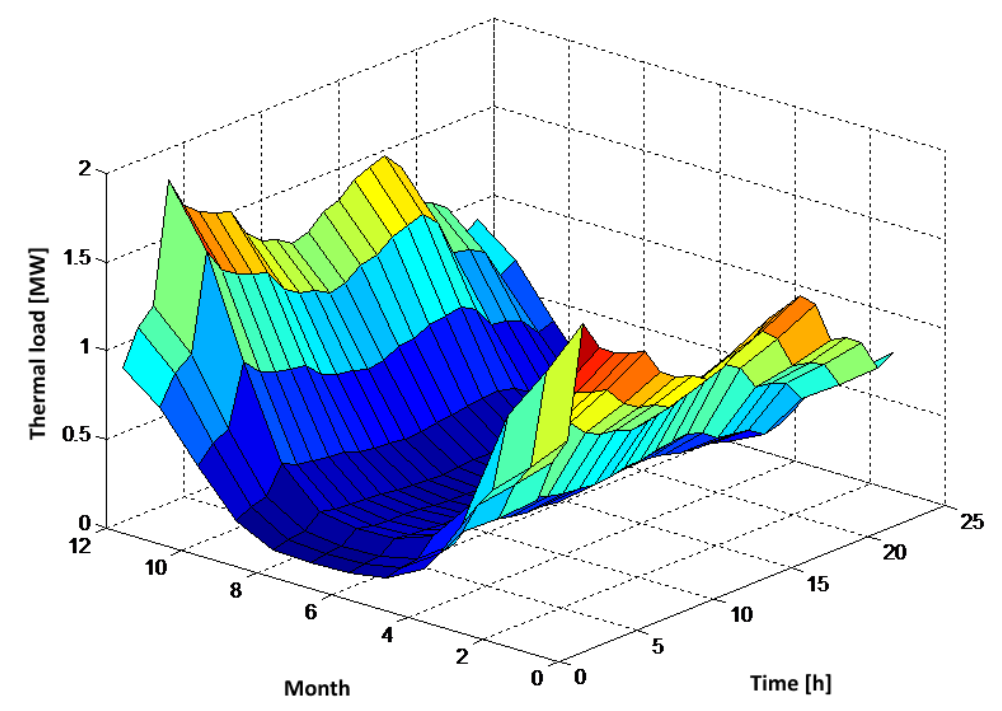

Figure 3. Daily heat load for Pokupsko DHS

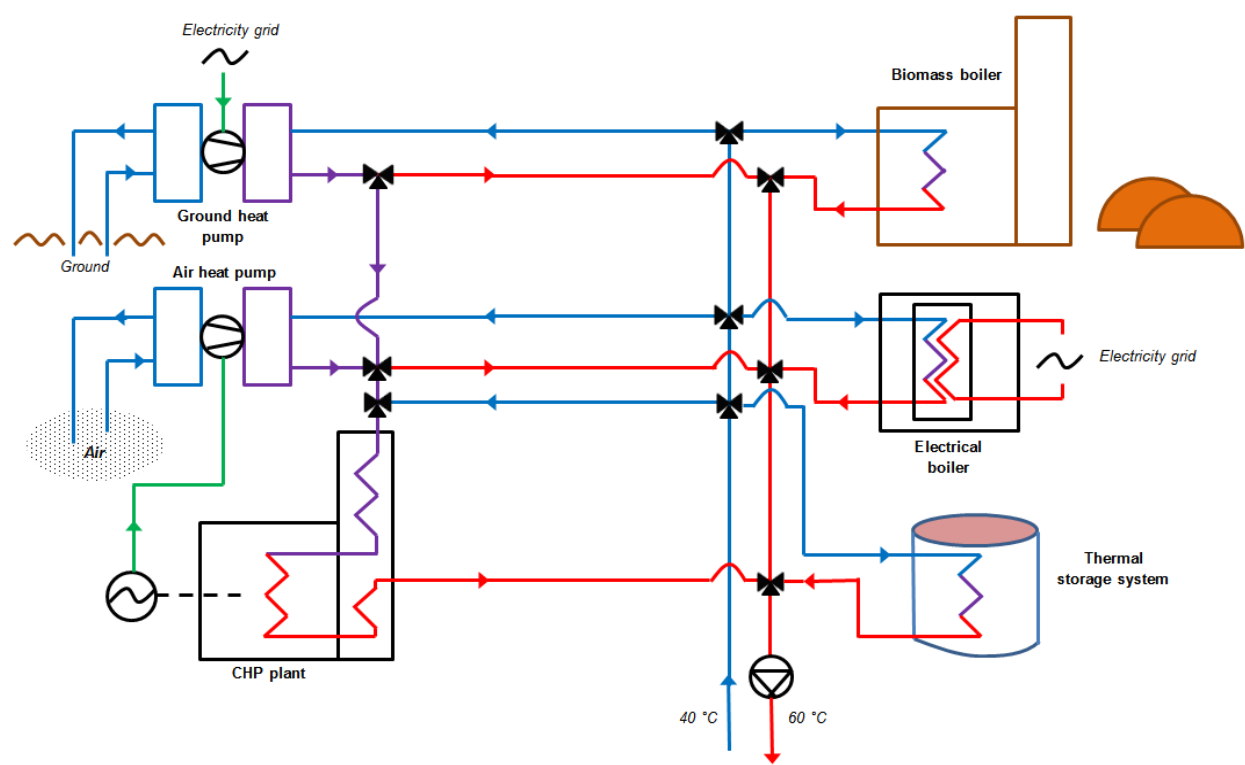

Figure 4. Scheme of hybrid district heating system

Due to variations in the heat demand, it is assumed that heat generation facilities (the biomass boiler, the CHP plant) would have to operate on different loads during the day in order to meet heat demand. Due to air temperature variations during the day (and month), air heat pumps will have variation in COP during DHS operation. The efficiency of the CHP micro-turbine is calculated as a ratio of total produced energy (heat and electricity) and total energy introduced with the fuel. It depends on operation power-to-heat ratio. In 
operation, the CHP micro-turbine will have to change the power-to-heat ratio in order to satisfy the particular heat demand. The efficiency can reach up to 75\% [56]. The efficiency of a biomass fired boiler is dependable on its load. On lower loads, the efficiency of a boiler is very low while on higher loads, the efficiency can reach up to 84\% [57, 58]. The COP of an air heat pump mostly depends on the difference between external (ambient) and outgoing water temperature. When the difference between these two values is large, COP of the system is small. COP of AHP can reach up to 5.2 [59]. $\mathrm{COP}$ of a ground heat pump is constant due to relatively constant ground temperature and it is set to be 2.7 [59]. Efficiency of the electrical boiler is set to be $90 \%$.

\section{RESULTS AND DISCUSSION}

The system optimisation method described in the mathematical model section has been performed in order to analyse the performance of different hybrid DHSs and to calculate an average heat production cost (on a yearly basis). The calculation has been done for 8 different cases that are described in Table 5. The maximum thermal output of

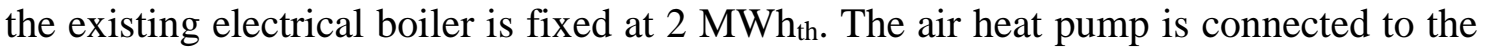
CHP generator and its output depends on power output generated in CHP system and current COP. The total capacities of other DHS facilities have been varied in order to find optimum values. Case 1 represents the existing case. In Case 2 a proposed system without optimisation of facility capacities has been analysed (in order to show operation of first optimisation algorithms). In the other cases, optimisation algorithms for system capacity optimisation have been implemented.

Table 5. Hybrid DHS test cases

\begin{tabular}{|c|c|c|c|c|c|c|c|c|}
\hline \multicolumn{2}{|c|}{ DHS configuration } & $\begin{array}{c}\mathrm{CHP} \\
{\left[\mathrm{MW}_{\mathrm{th}}\right]}\end{array}$ & $\begin{array}{c}\text { Air } \\
\text { source } \\
\text { heat } \\
\text { pump } \\
{\left[\mathrm{MW}_{\mathrm{th}}\right]}\end{array}$ & $\begin{array}{c}\text { Ground } \\
\text { source } \\
\text { heat } \\
\text { pump } \\
{\left[\mathrm{MW}_{\text {th }}\right]}\end{array}$ & $\begin{array}{c}\text { Biomass } \\
\text { boiler } \\
{\left[\mathrm{MW}_{\mathrm{th}}\right]}\end{array}$ & $\begin{array}{c}\text { Electrica } \\
1 \text { boiler } \\
{\left[\mathrm{MW}_{\mathrm{th}}\right]}\end{array}$ & $\begin{array}{c}\text { Thermal } \\
\text { heat } \\
\text { storage } \\
{\left[\mathrm{MWh}_{\mathrm{th}}\right]}\end{array}$ & $\begin{array}{l}\text { Heat cost } \\
\text { [EUR/ } \\
\text { MWh] }\end{array}$ \\
\hline \multirow{2}{*}{$\begin{array}{c}\text { Case } \\
1\end{array}$} & Considered & - & - & - & - & $\sqrt{ }$ & - & \multirow[b]{2}{*}{111.11} \\
\hline & $\begin{array}{l}\text { Proposed } \\
\text { capacity }\end{array}$ & - & - & - & - & 2.00 & - & \\
\hline \multirow[b]{2}{*}{$\begin{array}{c}\text { Case } \\
2\end{array}$} & Considered & $\sqrt{ }$ & $\sqrt{ }$ & $\sqrt{ }$ & $\sqrt{ }$ & $\sqrt{ }$ & - & \multirow[b]{2}{*}{98.35} \\
\hline & $\begin{array}{l}\text { Proposed } \\
\text { capacity }\end{array}$ & 0.50 & 0.30 & 0.60 & 0.50 & 2.00 & - & \\
\hline \multirow{2}{*}{$\begin{array}{c}\text { Case } \\
3\end{array}$} & Considered & $\sqrt{ }$ & - & - & - & $\sqrt{ }$ & $\sqrt{ }$ & \multirow[b]{2}{*}{91.41} \\
\hline & $\begin{array}{l}\text { Optimal } \\
\text { capacity }\end{array}$ & 1.95 & - & - & - & 2.00 & 2.00 & \\
\hline \multirow{2}{*}{$\begin{array}{c}\text { Case } \\
4\end{array}$} & Considered & $\sqrt{ }$ & $\sqrt{ }$ & - & - & $\sqrt{ }$ & - & \multirow[b]{2}{*}{90.75} \\
\hline & $\begin{array}{l}\text { Optimal } \\
\text { capacity }\end{array}$ & 1.05 & 0.84 & - & - & 2.00 & - & \\
\hline \multirow{2}{*}{$\begin{array}{c}\text { Case } \\
5\end{array}$} & Considered & $\sqrt{ }$ & $\sqrt{ }$ & - & - & $\sqrt{ }$ & $\sqrt{ }$ & \multirow[b]{2}{*}{90.75} \\
\hline & $\begin{array}{l}\text { Optimal } \\
\text { capacity }\end{array}$ & 1.05 & 0.84 & - & - & 2.00 & 0 & \\
\hline \multirow[b]{2}{*}{$\begin{array}{c}\text { Case } \\
6\end{array}$} & Considered & $\sqrt{ }$ & - & $\sqrt{ }$ & - & $\sqrt{ }$ & - & \multirow[b]{2}{*}{67.35} \\
\hline & $\begin{array}{l}\text { Optimal } \\
\text { capacity }\end{array}$ & 1.65 & - & 0.83 & - & 2.00 & - & \\
\hline \multirow{2}{*}{$\begin{array}{c}\text { Case } \\
7\end{array}$} & Considered & $\sqrt{ }$ & - & $\sqrt{ }$ & - & $\sqrt{ }$ & $\sqrt{ }$ & \multirow[b]{2}{*}{67.35} \\
\hline & $\begin{array}{l}\text { Optimal } \\
\text { capacity }\end{array}$ & 1.65 & - & 0.83 & - & 2.00 & 0 & \\
\hline \multirow[b]{2}{*}{$\begin{array}{c}\text { Case } \\
8\end{array}$} & Considered & $\sqrt{ }$ & $\sqrt{ }$ & $\sqrt{ }$ & $\sqrt{ }$ & $\sqrt{ }$ & $\sqrt{ }$ & \multirow[b]{2}{*}{64.07} \\
\hline & $\begin{array}{l}\text { Optimal } \\
\text { capacity }\end{array}$ & 0 & 0 & 0 & 1.00 & 2.00 & 0 & \\
\hline
\end{tabular}


Optimal hourly operation loads (for all 8 cases) have been calculated for an average day in every month of the year. Optimal DHS configuration has been calculated for Cases 3-8. The example of an optimal hybrid DHS operation performance during one day in January for Case 2 is presented in Figure 5. In the beginning of a day only the biomass boiler and in-ground heat pumps are in operation. The biomass boiler is on maximum load due to model constraints. The GHP is on $60 \%$ of its maximum load. Around 4 AM when the first heat demand peak occurs, in operation are biomass boiler, ground heat pump and CHP system, together with the air heat pump. The AHP and the CHP system are on their maximum load. This causes increase of a specific heat production cost due to consumption of natural gas. Around 10 AM, the heat demand reaches its local minimum. The CHP system reaches its technical minimum of heat production and it goes out of operation. It is more economically viable to turn off the CHP system (and AHP) and to turn on the expensive electrical boiler than to reduce heat output of GHP and to operate CHP system on its minimum technical value. However, it causes increase of heat production due to high cost of heat production in electric boiler. When the heat demand reaches its second peak, the CHP system is turned back into operation. Similar calculations have been performed for all 8 cases.
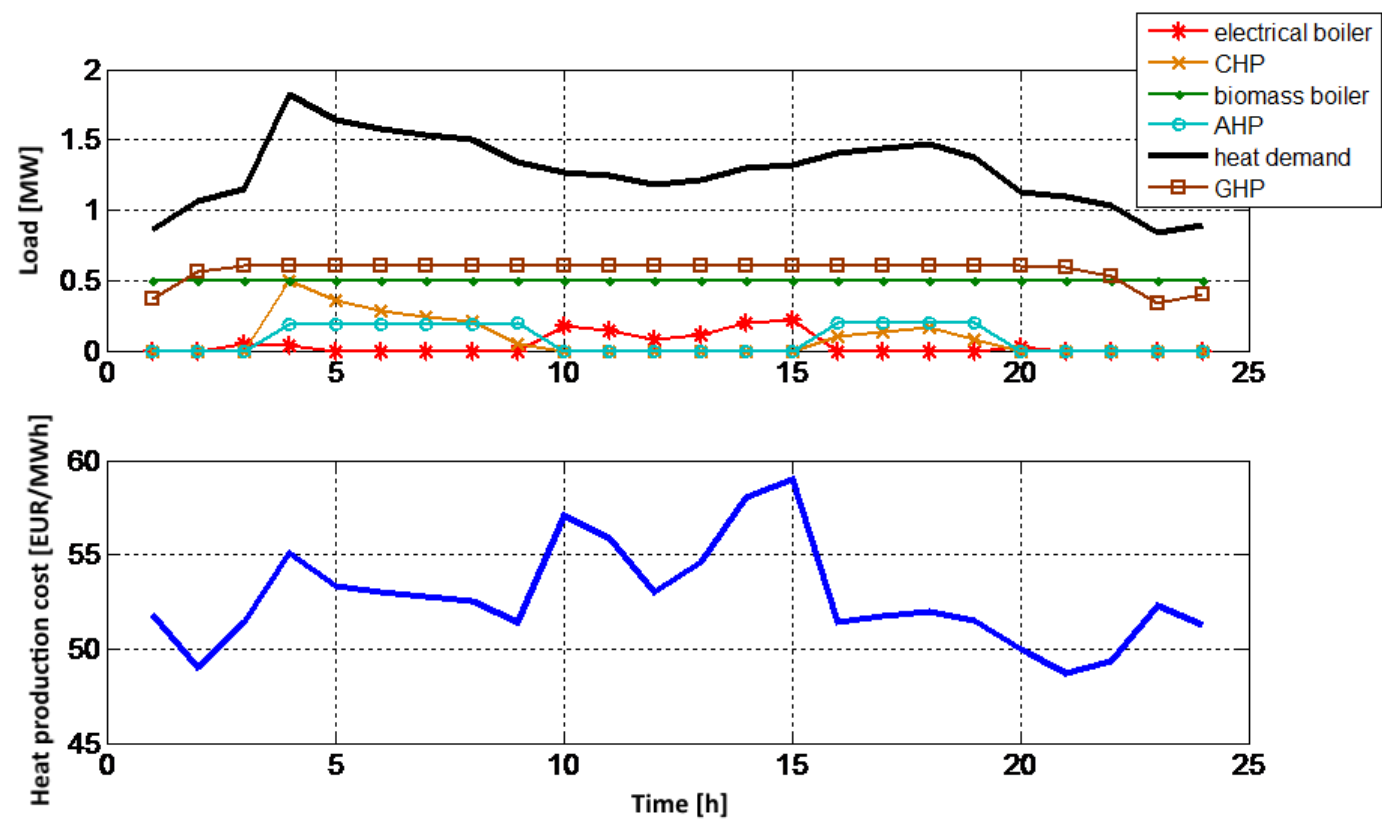

Figure 5. Operation of hybrid DHS for Case 2 (in January)

For DHS configuration optimisation, several cases have been considered (Cases 3-8). For some cases, some of the facilities have not been considered due to possible technical, environmental or other reasons. In cases where AHP is not considered it was assumed that all the electricity (that was produced by CHP facility) was sold to the utility at the normal electricity price (without subsidies).

In Case 3, where CHP and thermal storage facility have been considered, the maximum optimal thermal output of CHP facility has been set to be $1.95 \mathrm{MW}_{\text {th }}$. This implies that DHS is dimensioned in such a way that CHP facility could cover heat demand peaks and to operate during most of a day. The rest of the energy that is produced by CHP facility is stored in thermal storage system.

With introduction of AHP (that is connected to CHP system like in Cases 3 and 4) the necessity for thermal storage system drops and the heat production costs are reduced by $0.7 \%$. 
DHS where CHP facility and ground heat pump are in operation (Cases 6 and 7) shows a higher reduction in heat production costs. The maximum thermal output of CHP facility is reduced in comparison with Case 3 but increased in comparison with Cases 4 and 5. The flexibility of DHS has been improved with introduction of GHP which is now utilised to cover high heat demands and low heat demands during summer season.

In Cases 3-5, lower heat demands were covered by electrical boiler due to technical constraints of the CHP system. Due to high investment costs in thermal storage system, it is not economically viable to install such a system (under considered conditions) into DHS with CHP and GHP facilities.

In Case 8, all facilities were considered. However, the optimal system configuration comprises of $1 \mathrm{MW}_{\text {th }}$ biomass boiler which is used to cover low heat demands and heat demands during most of the year. To cover high heat demands the combination of biomass and electrical boiler is used. Heat production costs are reduced by almost $30 \%$ in comparison with DHS with only a CHP facility and more than $40 \%$ in comparison with the DHS with only an electrical boiler.

Simulation results from Cases 1-8 show that with current investment and fuel costs (Table 2) it is most economically viable to utilise biomass boiler together with electricity boiler for given heat loads. If biomass is not available then the optimal system configuration will consist of a CHP facility and a GHP. However, the heat production costs in that case will be increased by $5 \%$. Simulation results also show that a DHS that consists of CHP facility together with TSS has a lower heat production cost than a DHS without TSS.

Heat production cost and the DHS operation performance from the Case 8 have been shown in Figures 6 and 7. During the winter, heat production costs are below 70 EUR/MW th. This is a result of extensive use of biomass boiler. During the summer when the heat demand is low, specific prices for heat production are much higher. This is a result of averaged (on hourly basis) investment and O\&M costs that are introduced in heat production costs during lower heat demands. In this case, only the biomass boiler is utilised for heat production. During most of the year, heat demand is covered with operation of the biomass boiler. Electrical boiler is used only to cover peak loads during the winter season.

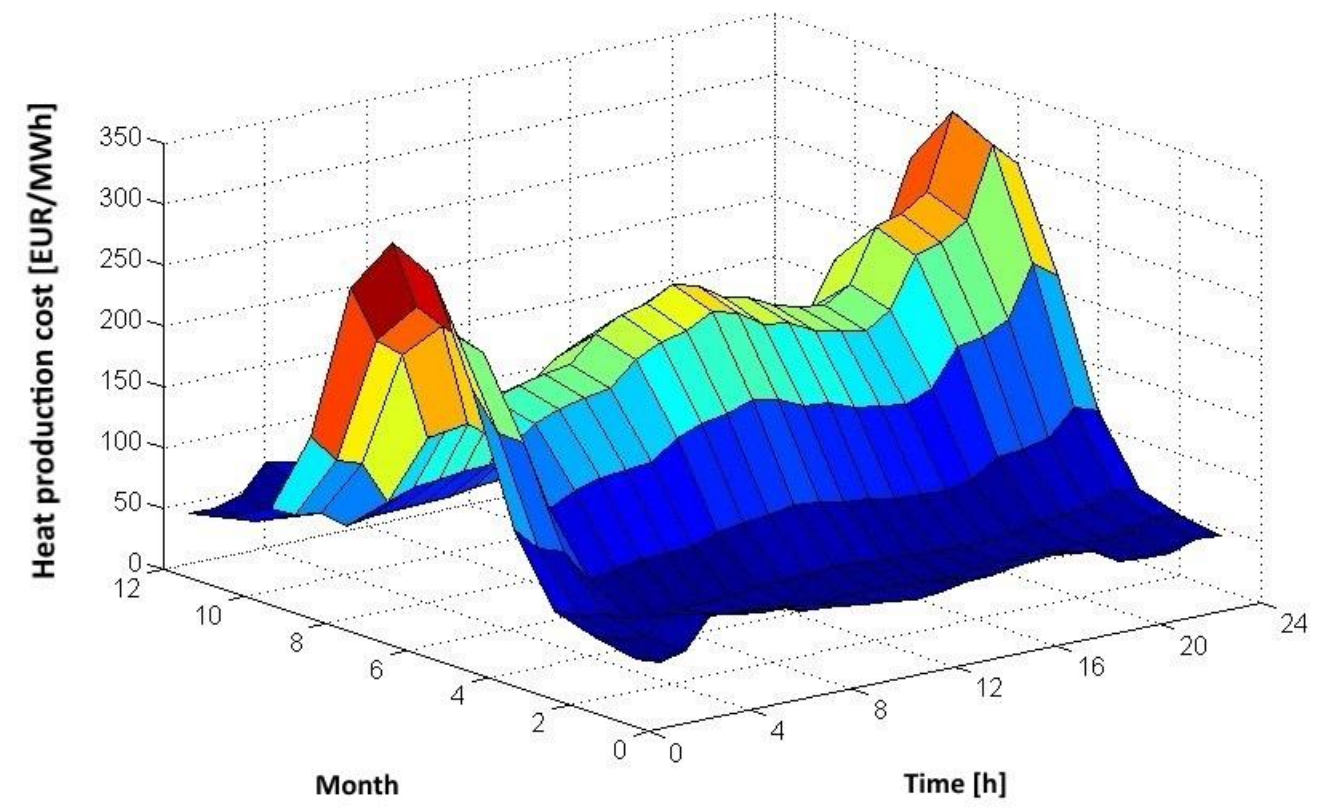

Figure 6. Heat production costs for Case 8 

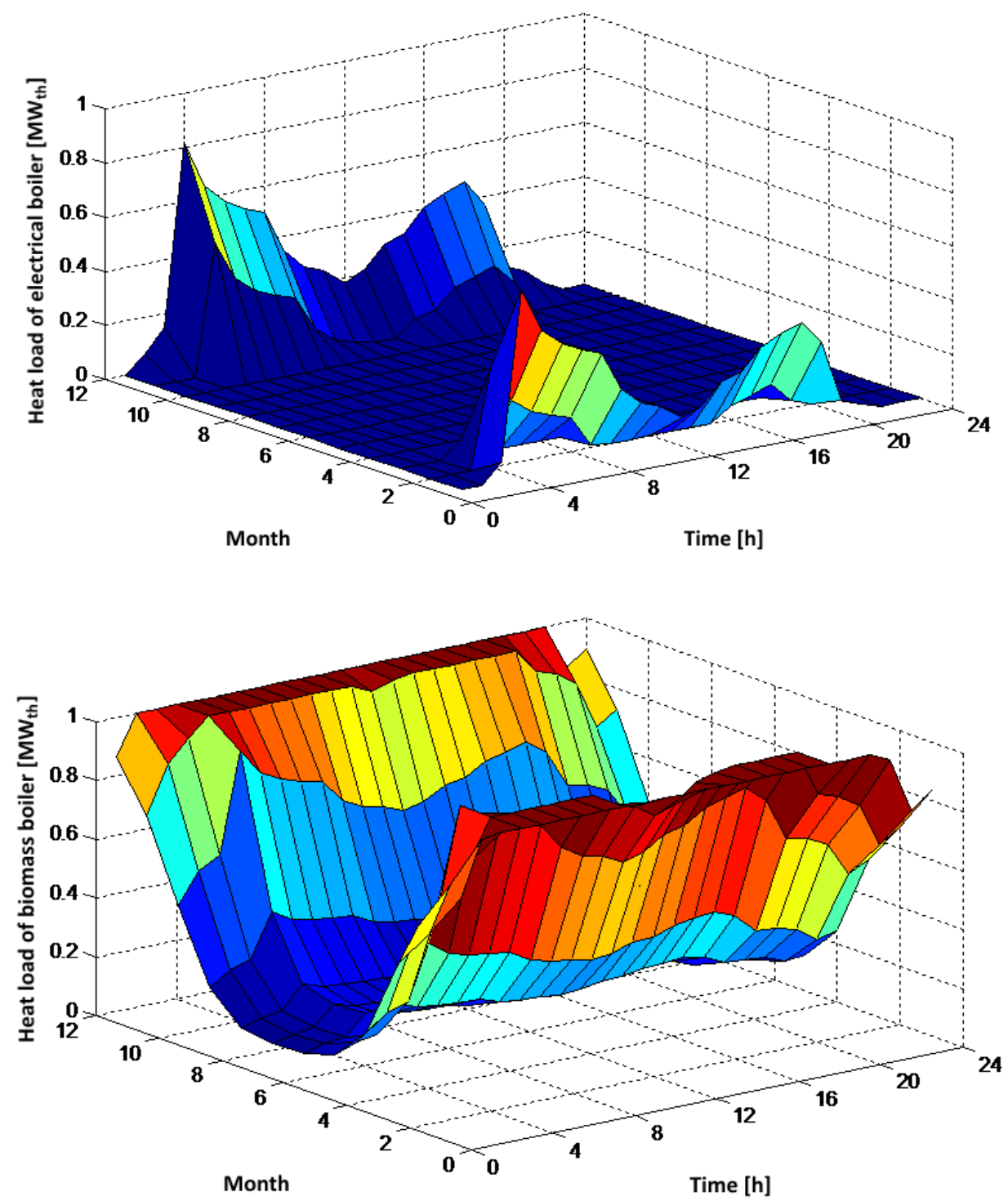

Figure 7. Optimal system operation for Case 8

Due to the methodology that has been used in this research, the accuracy of the determination of final heat production costs can be compared with the uncertainty of specific facility efficiency, investment costs, O\&M costs and fuel costs that can be found in $[22,24,44,46-50]$. For instance, investment costs for small CHP plant can range up to $\pm 25 \%$, for biomass boiler up to $\pm 15 \%$ and for AHP and GHP up to $\pm 10 \%$. Therefore, a sensitivity analysis of the optimisation model has been performed. For sensitivity analysis, several cases have been considered (Cases 9-12), described in Table 6. For each case an optimal system configuration and yearly averaged heat production price has been calculated. All facilities have been considered for possible implementation.

In Case 9, changes have been made in order to moderately encourage implementation of the heat pumps and thermal storage system. Despite the fact that the investment costs in such systems have been reduced, the optimal system configuration has not been changed considerably. Due to electricity cost increase, it is more economically viable to install a biomass boiler with higher maximal output to cover more heat demand during the year. Due to increase of biomass fuel prices, averaged heat production costs have been increased in comparison with Case 8 . 
In Case 10 the implementation of heat pumps and heat storage systems is encouraged even more. Therefore, the maximal thermal output of biomass boiler has been reduced and a GHP has been introduced. Due to a high increase of biomass fuel price and higher consumption of electricity, the average heat production costs have risen significantly.

In Case 11, where the implementation of heat pumps and heat storage systems has been highly encouraged, the system configuration has not been changed significantly. Due to smaller investment costs, the share of GHPs in fulfilling heat demand has been increased. Due to higher electricity prices (GHP consumes electricity from the grid) the heat prices have been increased. The overall impact of electricity cost increase on heat production price has been reduced with implementation of GHPs.

In Case 12, due to high electricity prices it is more economically viable to produce electricity from CHP system to power AHP than to use electricity from grid to power GHP. In Case 12 the DHS comprises of different technologies which shows that under conditions from Case 12 (described in Table 6) a hybridisation of DHS is highly encouraged. The overview of simulated average heat production costs for different cases is presented in Figure 8.

Table 6. Sensitivity analysis

\begin{tabular}{|c|c|c|c|c|}
\hline & Case 9 & Case 10 & Case 11 & Case 12 \\
\hline CHANGES & & & & \\
\hline Biomass price & $+30 \%$ & $+150 \%$ & $+150 \%$ & $+200 \%$ \\
\hline Gas price & $+10 \%$ & $+20 \%$ & $+25 \%$ & $-5 \%$ \\
\hline Heat pumps investment costs & $-15 \%$ & $-25 \%$ & $-40 \%$ & $-40 \%$ \\
\hline $\begin{array}{l}\text { CHP and biomass boiler investment } \\
\text { costs }\end{array}$ & $-5 \%$ & $-10 \%$ & $-15 \%$ & $-5 \%$ \\
\hline $\begin{array}{l}\text { Thermal heat storage investment } \\
\text { costs }\end{array}$ & $-10 \%$ & $-20 \%$ & $-30 \%$ & $-40 \%$ \\
\hline $\begin{array}{c}\text { Electricity cost } \\
\text { OPTIMAL VALUES }\end{array}$ & $+15 \%$ & $+20 \%$ & $+75 \%$ & $+100 \%$ \\
\hline $\mathrm{CHP}\left[\mathrm{MW}_{\mathrm{th}}\right]$ & 0 & 0 & 0 & 0.11 \\
\hline Air heat pump $\left[\mathrm{MW}_{\mathrm{th}}\right]$ & 0 & 0 & 0 & 0.09 \\
\hline Ground heat pump $\left[\mathrm{MW}_{\mathrm{th}}\right]$ & 0 & 0.05 & 0.30 & 0.1 \\
\hline Biomass boiler $\left[\mathrm{MW}_{\mathrm{th}}\right]$ & 1.20 & 0.90 & 0.90 & 0.90 \\
\hline Thermal heat storage [MWh] & 0 & 0 & 0 & 0 \\
\hline Heat production costs $\left[\mathrm{EUR} / \mathrm{MWh}_{\mathrm{th}}\right]$ & 66.89 & 86.05 & 88.17 & 98.55 \\
\hline
\end{tabular}

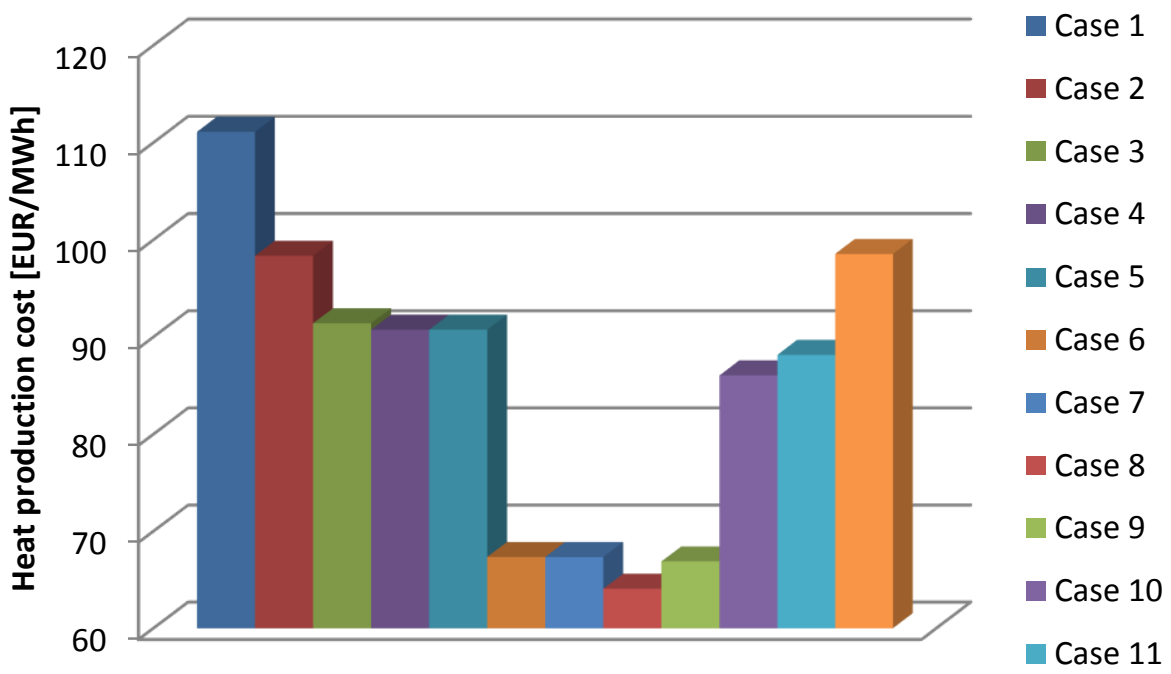

Figure 8. Average heat production costs for different cases 
With introduction of renewable energy sources (especially biomass and GHPs as in Cases 6-8), the average heat production costs are reduced in comparison with DHS that are comprised of non-renewable energy systems (Cases 3-5). Even with potential situations that are not favourable for biomass based DHS (Cases 9-11) the heat production costs are still lower than in CHP based DHS where the electricity is sold at current market price. The heat production costs are dependent on electricity cost (for heating purposes) but its influence could be reduced with implementation of different types of DHS configuration. With increasing biomass prices the increase of heat pumps share in DHS should be expected.

\section{CONCLUSION}

In this work, the economic performance of different types of a hybrid district heating system has been analysed. District heating systems have high potential as highly efficient and economically viable means of heat production. District heating systems have the possibility to implement larger amount of renewable energy in the existing energy system. A hybridisation of a district heating system combines two or more different (renewable or non-renewable) heat production systems that could complement each other on daily and yearly basis. To analyse the economic performance of a hybrid district heating system in Pokupsko district, a mathematical model has been developed. In comparison with the optimisation models from literature, the developed model enables optimisation of district heating system configuration and operation on yearly, monthly and daily basis where various district heating technologies can be considered. Simulation results from 8 different cases show that a hybridisation of district heating system has potential in terms of heat production cost reduction. The hybridisation of an existing district heating system with renewable and/or non-renewable based systems can reduce average heat production costs and improve the flexibility of the system. The effects of novel heat production technologies or waste heat utilisation in a district heating system could be analysed in future.

\section{ACKNOWLEDGEMENTS}

The work has been carried out under the scope of $4^{\text {th }}$ Generation District Heating Technologies and Systems project in cooperation among coordinator from University of Alborg, Denmark and partners from University of Zagreb, Croatia and The National Technical University "Kharkiv Polytechnic Institute", Ukraine.

\section{NOMENCLATURE}

$\begin{array}{llr}A & \text { area } & {\left[\mathrm{m}^{2}\right]} \\ c & \text { fuel costs } & \text { [EUR/MWh] } \\ C_{a v D H S} & \text { averaged total heat production costs } & {\left[\mathrm{EUR} / \mathrm{MWh}_{\mathrm{th}}\right]} \\ C_{i n} & \text { investment and operation and maintenance costs } & {\left[\mathrm{EUR} / \mathrm{MWh}_{\mathrm{th}}\right]} \\ c_{i n} & \text { specific investment cost } & {[\mathrm{EUR} / \mathrm{kW}]} \\ c_{O \& M} & \text { specific operation and maintenance costs } & {[\mathrm{EUR} / \mathrm{kW} / \mathrm{a}]} \\ C_{t h} & \text { costs of heat production } & {[\mathrm{EUR} / \mathrm{MWh}} \\ C_{t h D H S} & \text { total costs of heat production } & \text { [EUR/MWh } \\ C_{t o t} & \text { total heat production costs } & {\left[\mathrm{EUR} / \mathrm{MWh}_{\mathrm{th}}\right]} \\ i & \text { hour in a day } & {[-]} \\ j & \text { month in a year } & {[-]}\end{array}$




\begin{tabular}{llc}
\hline$P_{e l}$ & electrical output & {$\left[\mathrm{MW}_{\mathrm{el}}\right]$} \\
$P_{t h}$ & thermal output & {$\left[\mathrm{MW}_{\mathrm{th}}\right]$} \\
$P_{t h D H S}$ & heat demand & {$\left[\mathrm{MW}_{\mathrm{th}}\right]$} \\
$P_{t h \max }$ & maximal thermal output & {$\left[\mathrm{MW}_{\mathrm{th}}\right]$} \\
$P_{t h \min }$ & minimal thermal output & {$\left[\mathrm{MW}_{\mathrm{th}}\right]$} \\
$Q$ & stored energy & {$[\mathrm{MWh}]$} \\
$r$ & discount rate & {$[\%]$} \\
$\Delta T$ & temperature difference & {$\left[{ }^{\circ} \mathrm{C}\right]$} \\
$y$ & economic lifetime & {$[$ years $]$}
\end{tabular}

\section{Greek symbols}

$\eta$

$\alpha$

Subscripts
el
$i$
$h$
$m$
$\max$
$\min$
$O P T$
th

efficiency

convection factor of a slowly moving air
[\%]

$\left[\mathrm{W} / \mathrm{m}^{2} \mathrm{~K}\right]$

\section{REFERENCES}

1. Rezaie, B., Rosen, M., District Heating and Cooling: Review of Technology and Potential Enhancements, Applied Energy, Vol. 93, pp 2-10, 2012, http://dx.doi.org/10.1016/j.apenergy.2011.04.020

2. Lund, H., Möller, B., Mathiesen, B. V., Dyrelund, A., The Role of District Heating in Future Renewable Energy Systems, Energy, Vol. 35, pp 1381-1390, 2010, http://dx.doi.org/10.1016/j.energy.2009.11.023

3. Krajacic, G., Duic, N., Zmijarevic, Z., Mathiesen, B. V., Anic-Vucinic, A. and Carvalho, M. G., Planning for a 100\% Independent Energy System based on Smart Energy Storage for integration of Renewables and $\mathrm{CO}_{2}$ Emissions reduction, Applied Thermal Engineering, Vol. 31, pp 2073-2083, 2011, http://dx.doi.org/10.1016/j.applthermaleng.2011.03.014

4. Cosic, B., Krajacic, G. and Duic, N., A 100\% Renewable Energy System in the year 2050: The Case of Macedonia, Energy, Vol. 48, pp 80-87, 2012, http://dx.doi.org/10.1016/j.energy.2012.06.078

5. Mathiesen, B. V., Lund, H. and Connolly, D., Limiting Biomass Consumption for Heating in 100\% Reneweable Energy Systems, Energy, Vol. 48, pp 160-168, 2012, http://dx.doi.org/10.1016/j.energy.2012.07.063

6. Ahvenniemi, H. and Klobut, K., Future Services for District Heating Solutions in Residential Districts, Journal of Sustainable Development of Energy, Water and Environment Systems, Vol. 2, pp 127-138, 2014, http://dx.doi.org/10.13044/j.sdewes.2014.02.0012

7. Connolly, D. and Mathiesen, B. V., Heat Roadmap Europe 2050, Aalborg: Aalborg University, 2011.

8. Nuytten, T., Claessens, B., Paredis, K., Van Bael, J and Six, D., Flexibility of a Combined Heat and Power System with Thermal Energy Storage for District Heating, 


Applied Energy, Vol. 104, pp 583-591, 2013,

http://dx.doi.org/10.1016/j.apenergy.2012.11.029

9. Kuosa, M., Kontu, K., Mäkilä, T., Lampinen, M. and Lahdelma, R., Static Study of Traditional and Ring Networks and the use of Mass Flow Control in District Heating Applications, Applied Thermal Engineering, Vol. 54, pp 450-459, 2013, http://dx.doi.org/10.1016/j.applthermaleng.2013.02.018

10. Coskun, C., Oktay, Z. and Dincer, I., Performance assessment of a Novel Hybrid District Energy System, Applied Thermal Engineering, Vol. 48, pp 268-274, 2012, http://dx.doi.org/10.1016/j.applthermaleng.2012.04.052

11. Münster, M., Morthorst, P. E., Larsen, H., Bregnbaek, L., Werling, J., Lindboe, H. H. and Ravn, H., The Role of District Heating in the Future Danish Energy System, Energy, Vol. 48, pp 47-55, 2012, http://dx.doi.org/10.1016/j.energy.2012.06.011

12. Poputoaia, D. and Bouzarovski, S., Regulating District Heating in Romania: Legislative Challenges and Energy Efficiency Barriers, Energy Policy, Vol. 38, pp 3820-3829, 2010, http://dx.doi.org/10.1016/j.enpol.2010.03.002

13. Loncar, D. and Ridjan, I., Medium Term development Prospects of Cogeneration District Heating Systems in Transition Country - Croatian case, Energy, Vol. 48, pp 32-39, 2012, http://dx.doi.org/10.1016/j.energy.2012.07.025

14. Di Palma, D. and Lucentini, D., Trigeneration Plants in Italian Large Retail Sector: A Calculation Model for the TPF Projects with Evaluation of all the Incentivizing Mechanisms, Journal of Sustainable Development of Energy, Water and Environment Systems, Vol. 1, pp 375-389, 2013, http://dx.doi.org/10.13044/j.sdewes.2013.01.0028

15. Del Amo Sancho., Solar Trigeneration: A Transitory Simulation of HVAC Systems Using Different Typologies of Hybrid Panels, Journal of Sustainable Development of Energy, Water and Environment Systems, Vol. 2, pp 1-14, 2014, http://dx.doi.org/10.13044/j.sdewes.2014.02.0001

16. Badami, M., Casetti, A., Campanile, P. and Anzioso, F., Performance of a Innovative 120 kWe Natural Gas Cogeneration System, Energy, Vol. 32, pp 823-833, 2007, http://dx.doi.org/10.1016/j.energy.2006.06.006

17. Andersen, A. N. and Lund, H., New CHP Partnerships offering Balancing of Fluctuating Renewable Electricity Productions, Journal of Cleaner Production, Vol. 15, pp 288-293, 2007, http://dx.doi.org/10.1016/j.jclepro.2005.08.017

18. Lund, H., Andersen, A. N., Ostergaard, P. A., Mathiesen, B. V. and Connolly, D., From Electricity Smart Grids to Smart Energy Systems - A Market Operation Based Approach and Understanding, Energy, Vol. 42, pp 96-102, 2012, http://dx.doi.org/10.1016/j.energy.2012.04.003

19. Loncar, D., Duic, N. and Bogdan, Z., An Analysis of the Legal and Market Framework for the Cogeneration Sector in Croatia, Energy, Vol. 34, pp 134-143, 2009, http://dx.doi.org/10.1016/j.energy.2008.10.014

20. Kelly, S. and Pollitt, M., An assessment of the Present and Future opportunutues for Combined Heat and Power with District Heating (CHP-DH) in the United Kingdom, Energy Policy, Vol. 38, pp 6936-6945, 2010, http://dx.doi.org/10.1016/j.enpol.2010.07.010

21. Sartor, K., Quoilin, S. and Dewallef, P., Simulation and Optimisation of a CHP Biomass Plant and District Heating Network, Applied Energy, 2014, In publishing, http://dx.doi.org/10.1016/j.apenergy.2014.01.097

22. Mikulandric, R., Krajacic, G., Duic, N., Pranjic, Z., Khavin, G., Lund, H., Mathiesen, B. V., Proceedings of the International Conference on District Energy, Portoroz, Slovenia, 2013.

23. Zheng, G., Li, F., Tian, Z., Zhu, N., Li, Q. and Zhu, H., Operation Strategy Analysis of a Geothermal Step Utilization Heating System, Energy, Vol. 44, pp 458-468, 2012, http://dx.doi.org/10.1016/j.energy.2012.06.006 
24. Energy.gov, http://energy.gov/energysaver/articles/geothermal-heat-pumps, 2012, [Accessed: 20-October-2014]

25. Østergaard, P. A., Mathiesen, B. V., Möller, B. and Lund, H., A Reneweable Energy Scenario for Aalborg Municipality Based on Low-temperature Geothermal Heat, Wind Power and Biomass, Energy, Vol. 35, pp 4892-4901, 2010, http://dx.doi.org/10.1016/j.energy.2010.08.041

26. Østergaard, P. A. and Lund, H., A Renewable Energy System in Frederikshavn using Low-temperature Geothermal Energy for District Heating, Applied Energy, Vol. 88, pp 479-487, 2011, http://dx.doi.org/10.1016/j.apenergy.2010.03.018

27. Piskac, M., Prague District Heating System Application for 1st Global District Energy Climate Awards, Prague: Pražská teplárenská, 2009.

28. Verda, V., Guelpa, E., Kona, A. and Russo, S., Reduction of Primary Energy needs in Urban Areas trough Optimal Planning of District Heating and Heat Pump installations, Energy, Vol. 48, pp 40-46, 2012, http://dx.doi.org/10.1016/j.energy.2012.07.001

29. Mlyneaux, A., Leyland, G. and Favrat, D., Environomic Multi-objective optimisation of a District Heating Network considering Centralised and Decentralised Heat Pumps, Energy, Vol. 35, pp 751-758, 2010, http://dx.doi.org/10.1016/j.energy.2009.09.028

30. Mathiesen, B. V., Lund, H. and Connolly, D., Limiting Biomass Consumption for Heating in 100\% Reneweable Energy Systems, Energy, Vol. 48, pp 160-168, 2012, http://dx.doi.org/10.1016/j.energy.2012.07.063

31. Miao, Y. and Jia, Y., Hybrid Decentralised Energy for Remote Communities: Case Studies and the Analysis of the Potential Integration of Rain Energy, Journal of Sustainable Development of Energy, Water and Environment Systems, Vol. 2, pp 243-258, 2014, http://dx.doi.org/10.13044/j.sdewes.2014.02.0020

32. Li, Y., Fu, L., Zhang, S. and Zhao, X., A New Type of District Heating System based on Distributed Absorption Heat Pumps, Energy, Vol. 36, pp 4570-4576, 2011, http://dx.doi.org/10.1016/j.energy.2011.03.019

33. Blarke, M. B. and Dotzauer, E., Intermittency-friendly and High-efficiency Cogeneration: Operational Optimization of Cogeneration with Compression Heat Pump, Flue Gas Heat Recovery, and Intermediate Cold Storage, Energy, Vol. 36, pp 6867-6878, 2011, http://dx.doi.org/10.1016/j.energy.2011.10.008

34. Scarpa, F., Tagliafico, L. A. and Tagliafico, G., Integrated Solar-assisted Heat Pumps for Water Heating Coupled to Gas Burners; Control Criteria for Dynamic Operation, Applied Thermal Engineering, Vol. 31, pp 59-68, 2011, http://dx.doi.org/10.1016/j.applthermaleng.2010.08.012

35. Pardo, N., Monter, A., Martos, J. and Urchuegu, J. F., Optimization of Hybrid-ground Coupled and Air Source-heat Pump Systems in Combination with Thermal Storage, Applied Thermal Engineering, Vol. 30, pp 1073-1077, 2010, http://dx.doi.org/10.1016/j.applthermaleng.2010.01.015

36. Hackel, S. and Pertzborn, A., Effective Design and Operation of Hybrid Groundsource Heat Pumps: Three Case Studies, Energy and Buildings, Vol. 43, pp 3497-3504, 2011, http://dx.doi.org/10.1016/j.enbuild.2011.09.014

37. Li, F., Zheng, G. and Tian, Z., Optimal Operation Strategy of the Hybrid Heating System Composed of Centrifugal Heat Pumps and Gas Boilers, Energy and Buildings, Vol. 58, pp 27-36, 2013, http://dx.doi.org/10.1016/j.enbuild.2012.09.044

38. Pirouti, M., Bagdanavicius, A., Ekanayake, J., Wu, J. and Jenkins N., Energy Consumption and Economic Analyses of a District Heating Network, Energy, Vol. 57, pp 149-159, 2013, http://dx.doi.org/10.1016/j.energy.2013.01.065

39. Li, H. and Svendsen, S., District Heating Network Design and Configuration Optimization with Generic Algorithm, Journal of Sustainable Development of 
Energy, Water and Environment Systems, Vol. 1, pp 291-303, 2013, http://dx.doi.org/10.13044/j.sdewes.2013.01.0022

40. Morel, J., Obara, S. and Morizane, Y., Operation Strategy for a Power Grid Supplied by $100 \%$ Renewable Energy at a Cold Region in Japan, Journal of Sustainable Development of Energy, Water and Environment Systems, Vol. 2, pp 270-283, 2014, http://dx.doi.org/10.13044/j.sdewes.2014.02.0022

41. Andersen, A. N. and Lund, H., New CHP Partnerships Offering Balancing of Fluctuating Renewable Electricity Productions, Journal of Cleaner Production, Vol. 15, pp 288-293, 2007, http://dx.doi.org/10.1016/j.jclepro.2005.08.017

42. Henning, D., MODEST - An Energy System Optimisation Model applicable to Local Utilities and Countries, Energy, Vol. 22, pp 1135-1150, 1997, http://dx.doi.org/10.1016/S0360-5442(97)00052-2

43. Sundberg, G. and Henning, D., Investments in Combined Heat and Power Plants: Influence of Fuel Price on Cost minimised Operation, Energy Conversion and $\begin{array}{lllll}\text { Management, } & \text { Vol. } & 43, & \text { pp }\end{array}$ http://dx.doi.org/10.1016/S0196-8904(01)00065-6

44. Lako, P., Combined Heat and Power, Energy Technology Systems Analysis Programme, 2010.

45. Leyffer, S., Mahajan, A., Nonlinear Constrained Optimization, Argonne National Laboratory (Argonne, Illinois), 2010.

46. Centre for Alternative Technology, http://info.cat.org.uk/questions/heatpumps/how-much-will-heat-pump-cost, 2013, [Accessed: 20-October-2014]

47. Energy Sources, Production Costs and Performance of Technologies for Power Generation, Heating and Transport, Commission of the European Communities, 2008.

48. Hauer, A., Thermal Energy Storage - Technology Brief, IEA-ETSAP and IRENA, 2013.

49. Spirit Solar, http://www.spiritsolar.co.uk/air-source-vs-ground-source.php, 2013, [Accessed: 20-October-2014]

50. Gradska Plinara Zagreb, http://www.gpz-opskrba.hr/default.aspx?id=27，2012, [Accessed: 20-October-2014]

51. Hrvatska Elektroprivreda, http://www.hep.hr/ods/kupci/tarifni.aspx, 2013, [Accessed: 20-October-2014]

52. Hucika, H., Primjeri ESCO projekata u RH - Biomasa, 2010.

53. Google, https://maps.google.com/, 2013, [Accessed: 20-October-2014]

54. Katulic, S., Cehil, M., and Bogdan, Z. Optimization of Cogeneration Power Plant Operation Coupled with Heat Storage Tank used for District Heating of Zagreb Area, Croatia, Proceedings of the 7th Dubrovnik Concerence on Sustainable Development of Energy, Water and Environment Systems, Ohrid, Macedonia, 2012.

55. Joint Research Centre, Institute for Energy and Transport, http://re.jrc.ec.europa.eu/pvgis/, 2012, [Accessed: 20-October-2014]

56. Catalog of CHP Technologies, U.S. Environmental Protection Agency Combined Heat and Power Partnership, 2008.

57. Indoor

Comfort, http://www.indoorcomfortmarketing.com/want-green-want-an-energy-efficient-syst em.html/eff-drop-vs-load-curve, 2012, [Accessed: 20-October-2014]

58. Showers, G., Boiler operation efficiency, Boiler and Burner Systems, Cincinnati, Ohio, 2002.

59. Stafell, I., A Review of Domestic Heat Pump Coefficient of Performance, 2009. 
Paper submitted: 20.10.2014

Paper revised: 16.12.2014

Paper accepted: 02.01.2015 